\title{
ARTE RUPESTRE AFRICANO EN LAS CUEVAS DE CUBA. LA NECESIDAD DE UN CAMBIO EN LAS HERRAMIENTAS METODOLÓGICAS
}

\author{
Divaldo GutiÉRREZ CALVACHE ${ }^{\mathrm{i}}$ \\ GRUPO CUBANO DE INVESTIGACIONES DEL ARTE RUPESTRE (GCIAR) \\ Ilafer@infomed.sld.cu \\ JosÉ GONZÁLEZ TENDEROii \\ GRUPO CUBANO DE INVESTIGACIONES DEL ARTE RUPESTRE (GCIAR) \\ marinaglez@infomed.sld.cu \\ RACSO FERNÁNDEZ ORTEGA iii \\ GRUPO CUBANO DE INVESTIGACIONES DEL ARTE RUPESTRE (GCIAR) \\ itibacahuababa@yahoo.com
}

\section{RESUMEN}

Se presenta un análisis crítico de algunos de los presupuestos filosóficos, proyecciones teóricas, métodos y propuestas que se han utilizado como herramientas para intentar demostrar la posible ejecución de diseños rupestres cubanos por parte de individuos o grupos de africanos que, huidos de haciendas, ingenios, casas señoriales y convertidos en cimarrones, se refugiaban en los bosques y serranías del país, entre los siglos XVI y XIX. Este análisis demuestra que, hasta hoy, la mayoría de tales enfoques no han obtenido el resultado esperado, al estar concentrados en comparaciones morfológicas e inducciones mitologizadas de escasos alcances. La voluntad de obtener respuestas más certeras y efectivas ante esta problemática impone un rediseño de los presupuestos y métodos utilizados, así como un cambio en la forma de asumir el abordaje de las estaciones rupestres de posible factura africana.

Palabras Clave: Arte rupestre, petroglifos, africanos, esclavos, cimarrones, metodología.

i Investigador Asociado, Máster en Administración. Instituto Cubano de Antropología, Ministerio de Ciencia, Tecnología y Medio Ambiente.

ii Investigador Asociado. Instituto Cubano de Antropología, Ministerio de Ciencia, Tecnología y Medio Ambiente.

iii Investigador Auxiliar, Máster en Antropología. Instituto Cubano de Antropología, Ministerio de Ciencia, Tecnología y Medio Ambiente. 


\begin{abstract}
This paper presents a critical analysis of some philosophical elements, theoretical projections, methods and proposals used to attempt to demonstrate the possible African origin of certain Cuban rock art design, between the XVIth and XIX centuries. This analysis demonstrates that, until today, the majority of these approaches have not obtained the expected results, because they have been concentrated on morphological comparisons and mythological inductions of limited scope. In order to obtain more accurate and effective answers to this question becomes necessary a redesign of concepts and methods, as well as a change in the way rock art sites of possible African origin are approached.
\end{abstract}

KEYworDs: Rock art, petroglyphs, Africans, slaves, Cimarron, methodology.

\title{
INTRODUCCIÓN
}

Desde que el sabio cubano don Fernando Ortiz comenzara sus estudios sobre la presencia africana en la formación de la mezcla cultural, psicológica e ideológica que hoy definimos como "cubanidad", muchos han sido los investigadores que han realizado aportes singulares a esta faceta de la antropología cubana, entre los que cabría destacar a Rómulo Lachatañeré, José L. Franco, Rogelio A. Martínez Furé, Miguel Barnet, Jesús Guanche y otros. La arqueología, como ciencia que busca la evidencia material de las sociedades del pasado, tampoco ha estado ajena a esta situación: son significativos los trabajos arqueológicos en sitios de cimarronaje, llevados a cabo por estudiosos del tema, como Gabino La Rosa, Lourdes Domínguez, Enrique Alonso, Roger Arrazcaeta, etc.

Sin embargo, las investigaciones rupestrológicas han sido poco efectivas en el abordaje de la presencia africana en la confección y ejecución del arte rupestre en el archipiélago cubano. Para algunos autores, esta "ausencia" está determinada por la falta de intención de enfrentar una respuesta acabada al problema, al ser considerado el arte rupestre de manufactura africana como de escaso valor (La Rosa 2007: 73).

El planteamiento anterior resulta per se una idea muy personal, pues la búsqueda de las relaciones culturales o cronoculturales en el arte rupestre cubano no ha estado permeada de tal criterio. Tanto es así, que el propio La Rosa cita en su trabajo a más de quince estudiosos cubanos que, desde 1839 hasta la actualidad, han enfocado de una forma u otra esta posibilidad (La Rosa 2007: 70-73).

Ahora bien, si el objetivo de la crítica radica en la búsqueda de una "respuesta acabada", entonces la rupestrología cubana ha considerado de escaso valor a casi la totalidad de su gráfica rupestre, pues no existe tal respuesta para ningún grupo cultural de la historia cubana. Hoy no existe un método de investigación que sea capaz de dar una respuesta acabada a la filiación del arte rupestre cubano con grupos aborígenes arcaicos, agricultores, pre o post colombinos, castellanizados, etc. De hecho, la rupestrología hoy, a nivel internacional, no está en condiciones de dar respuestas acabadas a casi ningún enfoque cronocultural, pues aun ante la posibilidad de realizar dataciones absolutas de C14 por AMS, estas dejan margen de dudas, relacionadas con su efectividad cronológica, y no necesariamente tienen una implicación cultural (Nelson 1993 y Bednarik 2000).

Sin embargo, en los últimos años, han aparecido una serie de investigaciones que se han propuesto demostrar que individuos de origen africano o afrodescendientes ejecutaron manifestaciones rupestres en algunas estaciones cubanas. Al revisar estas investigaciones, se aprecia que en ellas no se han tenido en cuenta las limitaciones tangibles de coherencia que hoy presenta la rupestrología, entre paradigmas, teorías, métodos y resultados. Así, se presentan interpretaciones que enfocan el arte rupestre desde un esquema cerrado preconcebido, que lógicamente aseguraría el resultado previsto, al utilizarse presupuestos filosóficos tales como: "Dadas las condiciones del estudio y con los recursos disponibles, el análisis de las evidencias de la Cueva de los Ídolos debe ${ }^{1}$ emprenderse sobre la base de su posible correspondencia con los mitos y cultos de origen africano[...]" (La Rosa 2007: 79). 
Estos puntos de vista, generalmente, son portadores de una interesante acumulación de datos comparativos entre morfología del dibujo rupestre y mitología africana; pero no se acercan, ni someramente, al estado actual de la rupestrología. En ella los enfoques unidireccionales cedieron espacio a métodos que aseguran la comparación entre manifestaciones diversas, de forma tal que puedan evaluarse de manera objetiva sus similitudes y diferencias, a través de formulaciones estadísticas que permiten el uso de tipos y categorías basadas no en caracteres aislados, sino en conjuntos de ellos, factibles de analizarse mediante procedimientos de sistemática y filogenia -como la Cladística-, que sustenten la formulación de hipótesis bien fundamentadas sobre el desarrollo de las formas "artísticas" en un conjunto de unidades, y aseguren resultados fiables al momento de relacionarlas con la información cultural que aporte el registro arqueológico.

De ahí que en las próximas páginas realicemos una revisión crítica de las posiciones, presupuestos filosóficos, métodos y resultados de algunas de las propuestas que han intentado establecer una relación directa entre los grupos africanos y el arte rupestre del archipiélago cubano. La reflexión se sustenta en el análisis de la compleja variedad morfo-estilística del arte rupestre del Caribe insular, región etnocultural a la que pertenece Cuba, ya que aquellos estudios que aíslan el arte rupestre cubano de este entorno regional conducen, generalmente, a un enfoque equivocado.

No obstante, vale dejar claro que los autores no asumen una posición prejuiciada ante esta proposición, todo lo contrario: pensamos que es altamente coherente la hipótesis de que individuos de origen africano o sus descendientes ejecutaran manifestaciones rupestres en el país. Se admite aquí y, más aun, se defiende, que es probable que muchas de las asociaciones entre arte rupestre y grupos africanos expuestas en los trabajos analizados sean históricamente correctas, solo que los métodos y herramientas empleados para demostrarlas han sido insatisfactorios.

Antes de pasar a nuestro objetivo central, es oportuno dejar establecido que la trata negrera, comenzada como paliativo para compensar el exterminio indígena, trajo forzadamente al territorio cubano un nuevo sector poblacional, desarraigado socioculturalmente, compuesto por diferentes núcleos étnicos. Sus miembros, en muchos casos convertidos en cimarrones huidos de las haciendas, ingenios y plantaciones para luego apalencarse, debieron dejar en más de un lugar su huella cultural, expresada en particular por medio del arte rupestre; tradición ancestral que poseían en sus regiones de origen, donde el dibujo rupestre no es un objeto, sino un comportamiento: algo que se hace y que se vive en la acción; la obra plástica en su función de estimulante durante la adoración de un orisha, o la máscara en el movimiento de la danza.

Sin lugar a dudas, muchos de los códigos ideológicos relacionados con esta manifestación fueron mutilados cuando se redujo y limitó la movilidad del africano, negándosele la libertad como derecho natural e imponiéndosele asimilar nuevas lengua, religión y costumbres socioculturales. Ese individuo pudo reconquistar valores ancestrales al asumir el cimarronaje como forma de vida, de hecho, así se expresó con la propia huida. El cimarronaje preservaría gran parte de sus códigos y valores, en cánones debilitados por el doloroso estatus del esclavo, pero fortalecidos por el contacto generalmente sistemático (al menos durante los años que duró la trata) con nuevos grupos que arribaban a las plantaciones.

\section{Construcción de una hipótesis. ¿Perturbadora o insatisfactoria?}

En uno de los trabajos sobre esta temática, refiriéndose a algunos de los controvertidos petroglifos de la Cueva de los Ídolos, en la provincia Artemisa, el destacado arqueólogo e historiador cubano Gabino la Rosa Corso plantea: "No son necesarios grandes esfuerzos de la imaginación para comprender que la presencia de un perro, y la posición que tenía dentro del recinto, le confería el papel de guardián con el resto de las figuras; lo que en modo alguno, por la función asignada, puede vincularse con las culturas aborígenes que poblaron la isla de Cuba" (La Rosa 2007:78). 
O sea, "la presencia de un perro", su posición espacial y su "papel de guardián" aseguran una absoluta desvinculación con las culturas aborígenes cubanas. Llama la atención que se pueda aseverar tal planteamiento en el contexto arqueológico de las Antillas. Es necesario señalar que los estudios sobre la presencia del perro en la arqueología del Caribe insular han aportado un relevante caudal de información, que pone en dudas dicha afirmación. En la actualidad se posee el registro de más de 70 sitios arqueológicos aborígenes (37 de ellos cubanos), donde han aparecido asociadas evidencias de grupos precolombinos y restos óseos de cánidos. También se cuenta con un total de 77 piezas de las artes aborígenes representativas o relacionadas con el perro, y 13 conjuntos del arte rupestre con más de 29 diseños de este mamífero, distribuidos por República Dominicana, Barbados, Jamaica, Puerto Rico, Guadalupe, Martinica, San Eustaquio, San Kitts, Antigua, Montserrat, Santa Lucía, Granada y Cuba (Fig. 1).

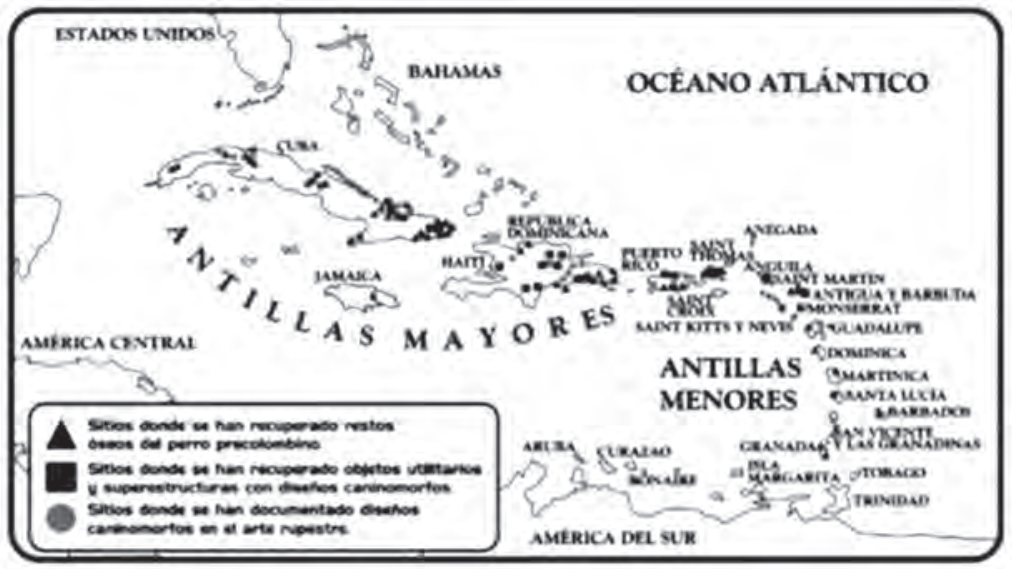

Figura 1. Mapa con la distribución de los hallazgos arqueológicos asociados al perro precolombino de las Antillas (Composición elaborada por los autores).

Todos estos datos han permitido conformar una percepción del perro en el arte rupestre: de una $u$ otra forma, este personaje parece cumplir un papel protagónico hacia el interior del conjunto en que aparece representado, papel que es resuelto por los ejecutores de diversas maneras, posiblemente en dependencia del mensaje que se deseaba transmitir en el espacio particular en que fuera ejecutado, y en relación directa con los restantes diseños asociados. Hasta el momento, el estudio de las imágenes de perros en la gráfica rupestre antillana ha permitido aislar cinco tipos de asociaciones significativas de la relación diseño-espacio (Tabla I).

$\mathrm{Al}$ analizar estas asociaciones, queda claro que la relación diseño-espacio, al menos para los motivos de cánidos presentes en el arte rupestre cubano y antillano, transporta una información social compleja. Su presencia al inicio de una secuencia, o a la entrada de una estación, ha sido aislada tanto para la Cueva de los Ídolos y la Cueva del Perro, en Cuba, como para la Cueva de la Línea o del Ferrocarril, o la Plaza Ceremonial de Caguana, en la República Dominicana, por solo citar algunas de las estaciones donde la imagen del perro forma parte de contextos rupestres y artefactuales que indican una probable filiación aborigen. Por ello, somos de la opinión que el uso y manejo de la relación espacial simple de un diseño caninomorfo no es un elemento resolutivo en el proceso de conformación de una propuesta sólida en cuanto al establecimiento de relaciones cronoculturales.

Por otra parte, y en este mismo orden, el estudio y análisis arqueológico de la figura de Opiyelguobirán -numen identificado con el perro en el panteón mitológico de los aborígenes de las 


\begin{tabular}{|l|l|}
\hline \multirow{5}{*}{$\begin{array}{l}\text { Distribución espacial del motivo perro } \\
\text { con relación a la estación y el conjunto } \\
\text { rupestre }\end{array}$} & $\begin{array}{l}\text { a) Recibe al espectador a su entrada al espacio sagrado e ini- } \\
\text { cia el desarrollo de la secuencia gráfica }\end{array}$ \\
\cline { 2 - 2 } & $\begin{array}{l}\text { b) Es parte del grupo de diseños primarios (3 primeros) en la } \\
\text { secuencia de la estación, utilizando como punto de partida la } \\
\text { entrada de la cavidad }\end{array}$ \\
\cline { 2 - 2 } & $\begin{array}{l}\text { ciones intermedias sin aparente carácter significativo, utili- } \\
\text { zando como punto de partida la entrada de la cavidad }\end{array}$ \\
\hline & $\begin{array}{l}\text { d) Es un diseño independiente y solitario en las oscuras gale- } \\
\text { rías de difícil acceso }\end{array}$ \\
\hline & $\begin{array}{l}\text { e) Se sobredimensiona la imagen logrando un efecto de prota- } \\
\text { gonismo por encima de todo el conjunto gráfico que lo rodea }\end{array}$ \\
\hline
\end{tabular}

Tabla I. Asociaciones diseño de perro-ubicación espacial que se han logrado aislar para el arte rupestre del Caribe insular (Elaborada por los autores a partir de Fernández, et al., 2012, inédito).

Antillas-, realizado por numerosos investigadores, ha demostrado que esta deidad, y su representación plástica en el arte rupestre y otras artes aborígenes, al parecer, cumplía una función de guardián entre el mundo de los vivos y el de los muertos. Lo cual indica que este personaje se mantenía en el área fronteriza y establecía la relación y el contacto entre el mundo de los vivos -la nueva generacióny el de los muertos -los antepasados- (Fernández et al. 2012, inédito) o, como plantea José Oliver:

Opiyelguobirán tiene la obligación de mantener a los seres vivos y no vivos, en el mundo que le es apropiado. Controlando - por así decirlo- lo que entra y lo que sale de un dominio al otro. Este es un personaje mediador que marca la separación y, a la vez, mantiene el balance entre ambos mundos al regular el tránsito de espíritus en el tiempo (día vs. noche) adecuado (Oliver 1998: 114).

Más adelante, La Rosa, en el trabajo que hemos estado comentando, plantea, refiriéndose al petroglifo del perro de la Cueva de los Ídolos: "En ese mismo sentido parece apuntar el tipo de perro que se talló, cuya figura no guarda relación con las reconstrucciones arqueológicas que se han hecho del famoso perro mudo de los aborígenes de la mayor de las Antillas" (La Rosa 2007: 78).

Resulta difícil comprender los presupuestos que dan origen a tal afirmación, pues la arqueología no ha realizado una reconstrucción integral del perro precolombino de las Antillas, al menos que los autores de este trabajo conozcan. Sin embargo, la paleozoología sí ha realizado la identificación de este como representante de Canis familiaris, sosteniendo que el conocimiento actual de la morfología de los restos de cánidos encontrados en Cuba permite asegurar que todas las variaciones morfológicas, señaladas por otros especialistas, son variaciones individuales presentes en numerosos ejemplares contemporáneos. Por su parte, las crónicas de Indias son poco precisas y contradictorias en elementos morfológicos, o sea, que lo único que se puede afirmar, con algún grado de certeza, es que el perro precolombino fue un animal muy similar al perro común de hoy.

Para finalizar estos comentarios, es imprescindible aceptar que, si de morfología se trata, nos parece bastante temerario el análisis morfológico-comparativo del diseño caninomorfo de la Cueva de los Ídolos, propuesto por La Rosa (2007: 78); si se tiene en cuenta que en este solo se pueden identificar algunos rasgos de la cabeza, lo que limita la comparación con las descripciones de los cronistas, con otras figuras del perro en el arte rupestre y con los modelados en cerámica, que son, en definitiva, los únicos elementos de comparación que posee hoy la arqueología de nuestra área geográfica.

En otro orden, algunos autores que siguen esta línea de investigación han intentado establecer o definir los tipos, categorías o características que pueden identificar al arte rupestre de factura u 
origen africano en las condiciones de las serranías de Pinar del Río. Este es el caso, por ejemplo, de la colega María Rosa González Sánchez, que sostiene:

En primer lugar el entorno geográfico seleccionado por el cimarrón para asentarse debía reunir, entre los requisitos más elementales, la distancia, es decir como mayor aislamiento posible de todo núcleo de población colonial así como de cualquier vía de comunicación para poder enfrentar una subsistencia acosada. Por otra parte, la inaccesibilidad, o sea, lugares de difícil acceso o poco accesibles al transeúnte, campesino o montero y con pocas probabilidades de ser descubierto ocasionalmente y camuflaje, un lugar que reuniese características topográficas y de vegetación que brindara protección (González 2008: sp.).

Un análisis simple de la cita anterior demuestra que está plagada de una contemporaneidad inaceptable, y en nada aplicable a un enfoque geoarqueológico o de arqueología del paisaje. El hecho de que una estación rupestre esté en la actualidad en un lugar aislado de núcleos poblacionales y vías de comunicación, sea inaccesible, intrincada y esté protegida por abundante vegetación, no le reporta ninguna especificidad cultural agregada, pues sencillamente en épocas precolombinas la mayoría absoluta de las cuevas y cavernas de las serranías pinareñas presentaba dichas características. Probablemente, muchas de las estaciones de fácil acceso en la actualidad fueron, antes del siglo XV, lugares mucho más inaccesibles que los que hoy consideramos apartados y pretendemos asignar a los grupos de origen africano.

También la referida investigadora considera que la distribución espacial del arte rupestre, dentro de las cavidades, es un elemento que puede aportar evidencias en pos de definir la filiación cultural: "Tanto los dibujos como los rayados, se localizan en las áreas oscuras de las cuevas. Elemento este, que generalmente predomina en todos los sitios con pictografías asociados a los cimarrones. Esta característica difiere para los sitios con pictografías de aborígenes, donde se localizan las mismas en las partes claras de la cueva" (González 2008: sp.).

Aun cuando este punto de vista pudiera ser correcto, observamos en el trabajo que, desafortunadamente, no está sostenido por un estudio estadístico que más que argumentarlo, lo demuestre, sin dejar margen a la duda. En este sentido, sin detenerse demasiado en este tema, baste señalar, en primer lugar, que para argumentar criterios estadísticos estos deben estar sustentados en el análisis y cálculo de muestras representativas, que permitan llegar a conclusiones sostenibles; de lo contrario, nos alejamos del camino de la investigación para introducirnos en un peligroso ambiente especulativo, antagónico con el de la ciencia.

Ahora bien, la necesidad de valorar muestras representativas, con la mayor cantidad de variables medibles, que permitan relaciones sostenibles en el campo de la teoría y la praxis arqueológica, se evidencia, por ejemplo, en una simple comparación entre las opiniones de los propios autores antes citados. Así, La Rosa contradice lo comentado por González Sánchez: “[...] la figura del perro, la primera que se localiza a la derecha entrando al recinto, estuvo tallada en un bloque[...]. El bloque en que se había tallado la mujer y el pequeño recipiente con una jicotea, se localiza en el costado izquierdo de la cueva, o sea, al lado del perro[...]" (La Rosa 2007: 78).

Como ya indicamos con anterioridad, la colega González Sánchez plantea que el arte rupestre vinculado con los cimarrones se ubica en las áreas oscuras de las cuevas. De estos dos planteamientos nace un antagonismo: parte del arte rupestre de la Cueva de los Ídolos se encuentra en las cercanías de los accesos a la cavidad y en áreas subumbrales, como se puede observar en las topografías de la localidad publicadas por La Rosa (2007); mientras, según María Rosa González Sánchez, debía estar en áreas de oscuridad, para cumplir con los supuestos patrones africanos. Esta dicotomía podría ser salvada, tal vez, con el argumento de que se están analizando dos regiones diferentes del país.

Sin embargo, veamos otro ejemplo, en el que también se entra en contradicción. La Rosa considera la presencia de una "cruz de tipo cristiano" en la mano de una figura antropomorfa como un elemento que aleja la posibilidad de una vinculación con las culturas aborígenes: 
El carácter y naturaleza de las tallas y petroglifos, la presencia de una cruz de tipo cristiano en la mano de una de las figuras antropomorfas, de un perro guardián del recinto y otros elementos particulares de cada una de las piezas alejan toda posibilidad de una vinculación con las culturas aborígenes y por el contrario fundamentan el criterio de que se trata de un centro ceremonial de cultos de origen africano[...] (La Rosa 2007: 79).

¿Cómo, entonces, conciliar ambas opiniones, para el caso particular del diseño rupestre rojo de la Cueva del Cura² (Viñales, Pinar del Río), donde aparecen dos figuras antropomorfas con cruces de "tipo cristiano" en las manos (Fig. 2A), si este diseño está realizado en el área umbral, a unos escasos tres metros de la entrada de la cueva? Y ahora sí estamos hablando de una misma región del arte rupestre cubano.

Ante estos intentos de ubicar el arte rupestre en esquemas cronoculturales, a partir de supuestos elementos "diagnósticos", baste solo la figura 2B, donde se puede observar una figura antropomorfa con una "cruz de tipo cristiana" en la mano: este diseño forma parte de la piedra ceremonial indígena de Anamuya, en Higüey, La Altagracia, República Dominicana.
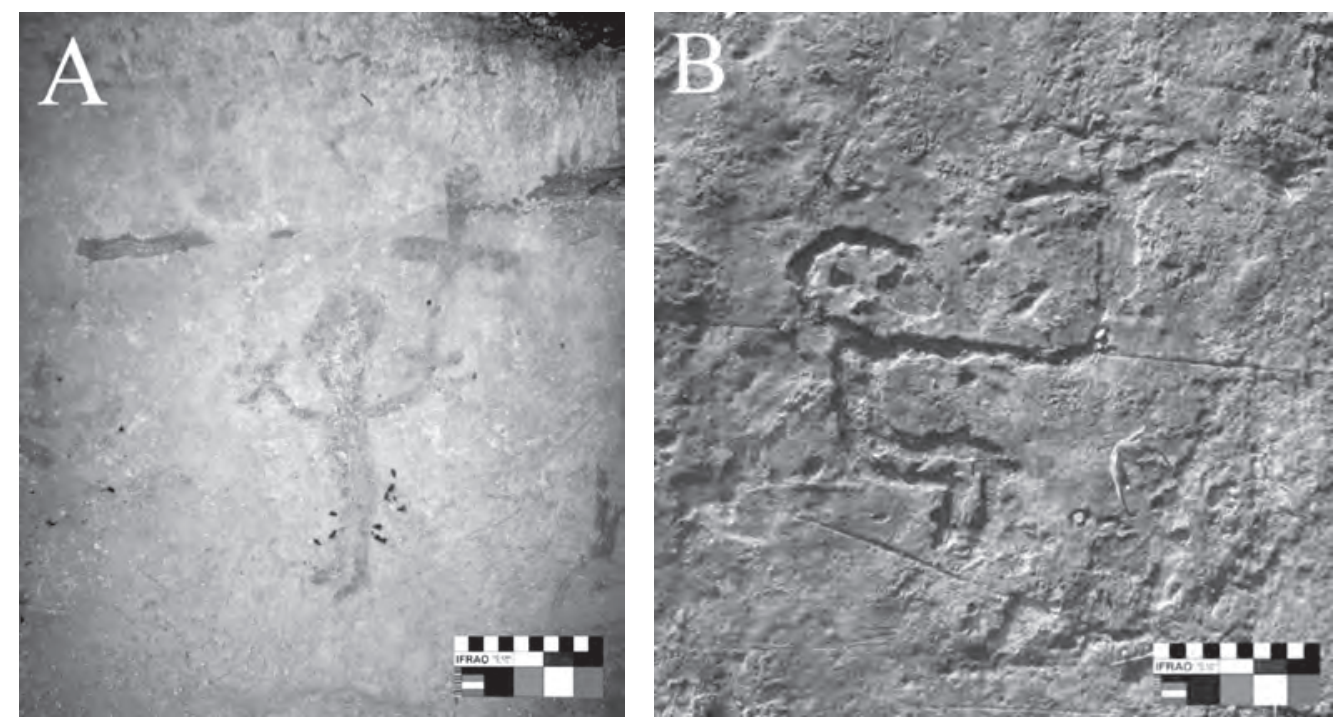

Figura 2. Diseños antropomorfos con figuras de cruz en sus manos, pertenecientes al arte rupestre antillano. (A) Pictografía en rojo de la Cueva del Cura, Viñales, Pinar del Río, Cuba y (B) Petroglifo de la Piedra Ceremonial de Anamuya, Higüey, La Altagracia, República Dominicana (Fuente: Archivos del GCIAR).

En trabajos más afortunados sobre este tema, se ha utilizado la presencia de objetos de los siglos XVI al XIX -como machetes calabozos, cuchillos, ollas de hierro colado, piedras de chispa, así como restos de fogones con evidencias de fauna postcolombina y otros elementos-, para argumentar la filiación africana (cimarrona) en algunas estaciones del arte rupestre cubano (La Rosa et al. 1990 y La Rosa 1992).

Ante tales argumentos, no pocos investigadores han reflexionado sobre el hecho incuestionable de que, en la mayoría de los casos, dichas evidencias solo aportan información temporal y no cultural; pues en su inmensa mayoría no son piezas de factura propiamente africana o cimarrona, sino obje-

2 Esta es una de las estaciones que la investigadora María Rosa González Sánchez considera de indudable factura cimarrona (González 2008: sp.). 
tos típicos de la época colonial. Solo en aquellos casos donde las evidencias están representadas por artefactos contenedores de cerámica transcultural, cachimbas o pipas y armas defensivas, es posible establecer rangos mayores de certeza ${ }^{3}$.

Entonces, cabe preguntarse: ¿por qué no aparecen muestras de arte rupestre en sitios donde es incuestionable la evidencia de haber constituido refugios de cimarrones? Sobre todo si admitimos que, bajo las condiciones de asedio y persecución que sufrieron los africanos fugados al monte (cimarrones), los sitios de habitación y rituales debieron en muchos casos confluir en espacios comunes. ¿Por qué no hay arte rupestre en la Cueva del Buda, o en la Cueva del Tambor, donde el desarrollo de las espeluncas permitía aislar las funciones de cada uno de sus recintos? ¿Por qué no hay arte rupestre en el Pan de Matanzas, en la Cueva de la Caja o en la Gruta Cimarrón 5? Estos, por solo citar algunos ejemplos.

Otra situación, que obliga a reflexionar sobre los presupuestos filosóficos manejados en la búsqueda de respuestas a la problemática planteada, es aquella que ha considerado la filiación africana de los diseños rupestres en función de su tamaño. Durante las jornadas del 1er. Simposio Internacional de Arte Rupestre, celebrado en La Habana, al evaluar la composición actual del arte rupestre cubano, y repasar los dibujos de la estación Solapa de María Antonia, en Pinar del Río, algunos investigadores cuestionaron si "un dibujo de ese tamaño podía haber sido elaborado por aborígenes, parecería más bien de origen africano, realizado por cimarrones" (Enrique Alonso com. pers., 24 de noviembre de 2008).

En ocasiones resulta sorprendente escuchar este tipo de opinión, conociendo en sentido general cómo se manifiesta el dibujo rupestre a lo largo de todo el país, y sobre todo si tenemos en cuenta que el dibujo más grande de la Solapa de María Antonia tiene unas dimensiones de $116.0 \mathrm{~cm}$. por $89.0 \mathrm{~cm}$.; mientras que el motivo central de la internacionalmente conocida Cueva No.1 de Punta del Este, en la Isla de la Juventud, presenta una extensión de $154 \mathrm{~cm}$ por $105 \mathrm{~cm}$. ¿Estamos ante un diseño de origen africano en Punta del Este?

Un caso peculiar en este tema es la magnífica obra Exploraciones en la plástica cubana, de Gerardo Mosquera (1983), en la cual su autor, a partir de comparaciones morfológicas, propone la hipótesis de que los petroglifos de la Sala García Valdés, en la Cueva de Mesa, Gran Caverna de Santo Tomás, Viñales, Pinar del Rio, son de factura africana, considerando la semejanza entre la morfología de sus diseños y los que aparecen adornando algunos objetos del cimarronaje rescatados en Vuelta Abajo.

Es indudable que la temprana ejecución de esta monografía no permitió a su autor conocer que el trabajo de los rupestrólogos cubanos ha ido definiendo y aislando un "estilo" o una forma de ejecución para este tipo de petroglifos, particularmente para el occidente de Cuba, determinándose que su morfología y técnica de ejecución se repite en las cuevas de Mesa, de los Petroglifos, de la Iguana, de la Cachimba y el Sistema Cavernario de Bellamar; así como en no pocos sitios de otras islas de las Antillas. Así, este tipo de arte rupestre, que en 1983 era escaso y casi único para la Cueva de Mesa, Gran Caverna de Santo Tomás, hoy es bastante común en numerosos sitios precolombinos del Caribe insular.

Ahora bien, retomando temas anteriores, y analizando algunos de los planteamientos que se han sugerido sobre la presencia de la "cruz de tipo cristiano" en la mano de una de las figuras antropomorfas en la Cueva de los Ídolos y en la Cueva del Cura -por citar solo estos dos ejemplos-, se hace necesario dejar establecido que "la cruz" como motivo ha sido encontrada en numerosas estaciones del arte rupestre cubano. Al respecto, se repite en muchos casos el criterio de considerarla cristiana, dándole así un sentido o "valor" cronológico y cultural. Tal es el caso, por ejemplo, del petroglifo de la

3 El caso de las cachimbas o pipas necesita una revisión detallada en la actualidad, pues si bien este era un artefacto considerado hasta hace muy poco ajeno a las culturas precolombinas del Caribe insular, el trabajo de investigadores dominicanos ha permitido conocer la presencia de pipas de factura aborigen en sitios de la Española y Puerto Rico (Veloz, s/f). 
Cueva del Indio, en la provincia de Artemisa, donde: "Las investigaciones llevadas a cabo condujeron a los arqueólogos a inferir la posible vinculación de la obra con manifestaciones de cultos de origen africano, al observar una vez más la presencia del motivo cruciforme en el supuesto pecho[...]" (La Rosa et al., 1990, según Pereira, 2008: 32).

Similar situación ha sucedido con el reciente hallazgo en la Cueva Grande, de Sierra de Cubitas, Camagüey, de un diseño en forma de cruz, que parece una réplica exacta de la cruz de la Cueva de Ambrosio, en Matanzas. Para esta localidad camagüeyana se ha planteado lo siguiente:

Resulta inevitable que surjan dudas con respecto al nexo con la cultura aborigen de semejante dibujo. El símbolo del cristianismo es la cruz y la única explicación a este respecto es que se trate de pictografías de origen en efecto, aborigen, pero correspondientes a una etapa de transculturación, de indios sometidos al proceso ideologizante de la evangelización que comenzó casi inmediatamente después de la conquista (Funes 2005: 62).

Ante esta inexplicable cruzada por el cristianismo en la rupestrología cubana, solo podemos aludir que la cruz como figura ha sido utilizada por casi todas las culturas de la humanidad, sin llevar implícito ningún apellido. El criterio de "cruz cristiana" es, por lo tanto, poco sólido y sostenible, pues parte de un signo o símbolo utilizado en todo el mundo, del cual pretendió apropiarse el cristianismo. Su representación aparece en el arte rupestre precolombino de las Antillas y de América en general (Fig. 3), de forma abrumadora. Pero si alguna duda quedara al respecto, remitimos al lector a uno de los diseños más interesantes del arte rupestre del hemisferio occidental: la piedra Huancor, en Perú (Fig. 3E), en la cual se encuentran representadas tanto la cruz andina, presente también en la Cueva No. 1 de Punta del Este, en la Isla de la Juventud, Cuba; como la cruz alunada, presente en la Cueva de Ambrosio, Matanzas, Cuba. Un caso particular aparece en la imagen 3D, perteneciente a la Cueva de la Línea o del Ferrocarril, Los Haitises, República Dominicana, donde vuelve a presentarse una figura antropomorfa con una cruz en su mano. Lo llamativo del hecho es que aparece acompañada por motivos ornitomorfos, realizados todos en negro, en una zona de oscuridad absoluta de la cavidad; este conjunto de caracteres se repite casi de forma idéntica en la Cueva del Cura, en Viñales, Pinar del Río, Cuba.

Otros elementos han sido utilizados para alejar la vinculación entre culturas aborígenes y arte rupestre de algunas estaciones cubanas, y proponer la presencia de ejecutores africanos o afrodecendientes. Por ejemplo, la propuesta sobre la aparente relación entre la talla del perro, la talla de un ser humano (una mujer) y la de un pequeño recipiente con una jicotea, presente en la Cueva de los Ídolos (La Rosa 2007: 78).

Al respecto, se puede argumentar que la relación perro - humano - jicotea o tortuga (la definición de jicotea en arte rupestre es algo arriesgada para asumirla como conclusiva) ha sido tratada en más de una oportunidad en las investigaciones arqueológicas de las Antillas. Un caso singular, que ilustra muy bien esta relación, es el de los elementos asociados dentro de un conjunto arqueológico en el sitio aborigen de Golden Rock, en la isla de San Eustaquio, Antillas Menores, donde los restos de un cánido precolombino aparecieron compartiendo el espacio funerario junto a un entierro humano aborigen de tipo primario, todos rodeando a una tortuga marina (Van der Klin 1992: 61). En este sentido, también es bueno recordar que la asociación perro - tortuga fue descrita de alguna forma para el hábitat cotidiano de nuestros aborígenes, por el cronista Andrés Bernáldez, cuando refirió que el Almirante Cristóbal Colón había visitado una aldea de la cual huyeron sus habitantes ante la llegada de los conquistadores, y en ella se encontraron como únicos animales numerosas tortugas junto a 40 perros (Bernáldez 1870; citado por Jiménez y Fernández 2002: 80). Por otra parte, cabe citar, como respuesta más acertada a la supuesta lejanía de las culturas aborígenes, lo planteado por Oscar Pereira: "Hay que tomar en cuenta que las imágenes como la jicotea, la serpiente, el sol y la cruz son representaciones también muy utilizadas por los indígenas precolombinos, tales iconos son elementos simbólicos de las concepciones mítico-religiosas, tanto de las culturas africanas como aborígenes" (Pereira 2008: 31). 


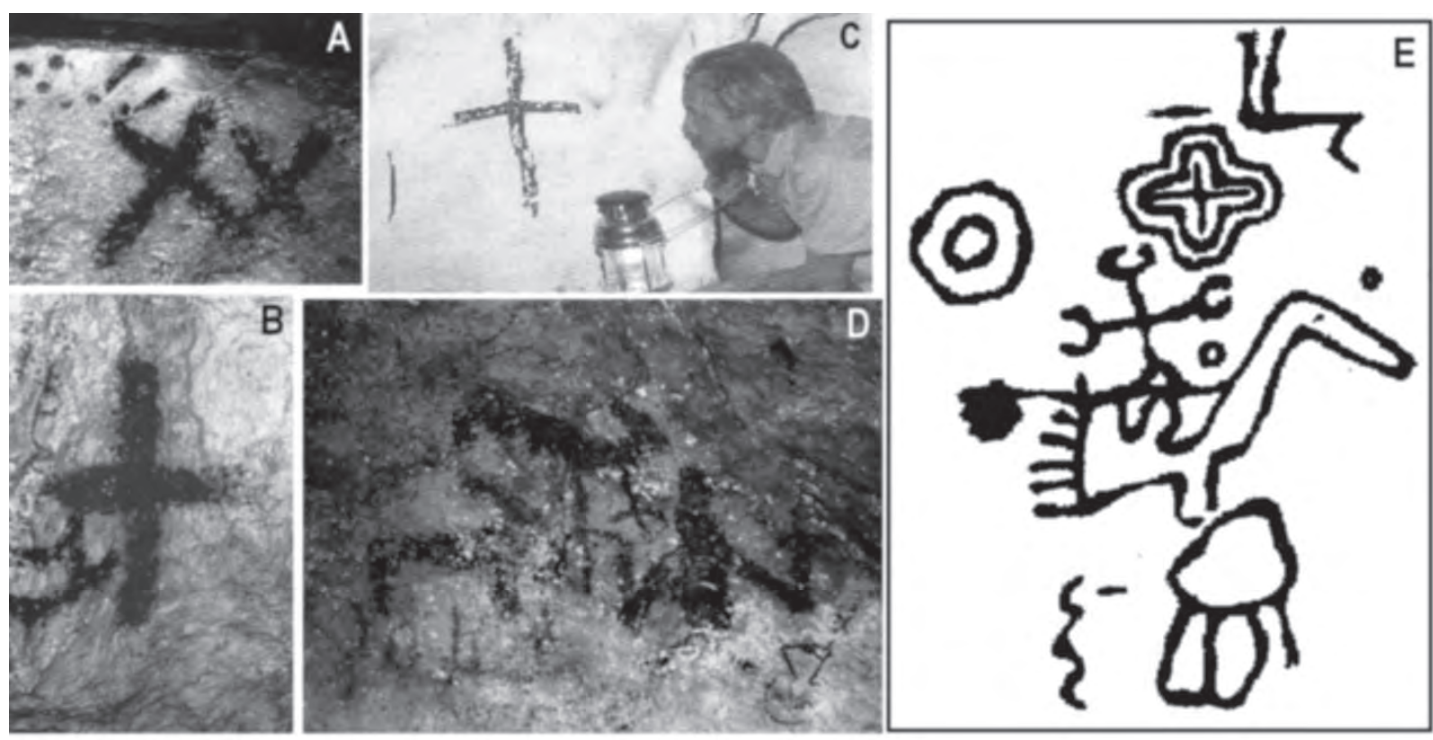

Figura 3. Diseños rupestres de cruces en el arte aborigen de las Antillas y América. (A) Pintura rupestre de dos cruces en negro de la Cueva de José María, La Altagracia, República Dominicana. (B) Cruz en color rojo de la Cueva de José María, La Altagracia, República Dominicana. (C) Cruz de la Caverna de las Cinco Cuevas, La Habana, Cuba. (D) Pintura rupestre de la Cueva de la Línea, Hato Mayor, República Dominicana, donde se observa una figura antropomorfa con una cruz en su brazo. (E) Petroglifo de la piedra Huancor, Perú, donde aparecen diversas variantes de figuras en cruz (Composición elaborada por los autores a partir de Núñez Jiménez 1975, 1985 y López Belando 2003).

Quizás el más polémico de los planteamientos que han sido publicados en los últimos años, sobre el tema aquí debatido, sea el del doctor Gabino La Rosa, cuando al referirse de forma particular a la figura solar de la Cueva de los Ídolos, expresa:

[...] pero no una figura del sol como la que pudiera haber representado un aborigen antillano, habituado a la síntesis y al lenguaje figurativo del ideograma. Es un sol y un rostro humano de expresión iracunda, situado no casualmente en lo alto del conjunto de tallas y petroglifos. Por su posición y tratamiento es fácil identificar en él a la deidad suprema de los yoruba: Olórum que es la manifestación de Olofin[...] (La Rosa 2007: 81).

Es importante agregar aquí que este planteamiento es consecuente con lo afirmado por la investigadora Deisy Fariñas, hace casi 15 años, cuando, refiriéndose a la figura solar en cuestión, escribió: “[...] un sol que es evidentemente africano, pues está representado con rostro humano y no con círculos concéntricos como usualmente hacían los aruacos" (Fariñas 1995: 88).

Aun aceptando la relación propuesta por Fariñas y La Rosa, una vez más, el tratamiento morfológico condiciona la relación mitológico-cultural, y se incurre de nuevo en el mismo error, al desestimar las amplias variantes que ofrece el arte rupestre aborigen de Cuba y las Antillas y, por tanto, de nuestro marco geocultural. En este caso, al expresar: "no una figura del sol como la que pudiera haber representado un aborigen antillano", el autor no da detalles de los criterios asumidos para establecer los caracteres diagnósticos que podrían permitir la clasificación de una figura solar como aborigen o africana; lo que sí intenta Deisy Fariñas, al proponer para los grupos aruacos del Caribe una dependencia entre diseños solares y círculos concéntricos.

Sin pretender extendernos demasiado en los problemas que presentan los criterios antes expuestos, se impone una reflexión. Por ejemplo, en ellos se desconoce la similitud evidente entre el diseño 
solar de la Cueva de los Ídolos y un precioso diseño solar aborigen del arte rupestre de la Cueva de la Línea o del Ferrocarril, Los Haitises, al norte de la República Dominicana; lo cual lógicamente cuestiona la validez de los argumentos de La Rosa y, por supuesto, impugna, en el campo del conocimiento, el criterio de los círculos concéntricos.

Más adelante en su trabajo, La Rosa (2007), al referirse a la representación gráfica de la deidad Olórum, expresa: "En otras representaciones de esta deidad se le ha dibujado como un sol con sus rayos en forma de pétalos y un rostro humano en el círculo central. También se representa como un girasol" (La Rosa 2007: 81). Ante este planteamiento, baste como ejemplo de la utilización de dichas categorías morfológicas en nuestra área geográfica y cultural, la reproducción de dos preciosas pinturas rupestres del arte rupestre aborigen de la isla de La Española (Fig. 4), elemento que se repite en el arte rupestre antillano en general.

Por otra parte, si entre los caracteres diagnósticos cronoculturales se asumen la presencia del rostro, su expresión y la ubicación del diseño, entonces nos enfrentamos a uno de los problemas cruciales que se detecta en la mayoría de los aportes al conocimiento del arte rupestre cubano. Nos referimos al desconocimiento de la riqueza del dibujo rupestre antillano, pues diseños rupestres solares con rostros son sumamente abundantes en nuestra área geográfica (Fig. 5). Estas imágenes se distribuyen dentro de las estaciones tanto en los lugares más altos como en los más bajos. En cuanto a sus expresiones, basten las figuras $5 \mathrm{~A}$ y $5 \mathrm{C}$, para ver un rostro alegre; o la figura $5 \mathrm{~F}$, para uno iracundo o, finalmente, la figura 5D, para un rostro asombrado. Así, de esta forma, el sol y las caras solares, con diversas expresiones faciales, son numerosos en el arte rupestre aborigen del Caribe insular. El número de sus representaciones no está documentado con exactitud; pero, para citar solo algún ejemplo, baste señalar que el investigador Adolfo López ha logrado aislar 127 figuras solares, en una sola estación de la República Dominicana: la Cueva de José María, al sureste de la isla de La Española (López 2003: 296), y ninguna de ellas está representada por círculos concéntricos.

Lo más curioso de los diseños de la figura 5 radica en el hecho de que, si son comparados desde la perspectiva morfológica, todos tendrán un singular parecido con las imágenes del sol que se emplean en las cazuelas y coronas de Ochún, Yemayá y Oyá, deidades de la santería afrocubana (Guanche, com. pers., junio 2009). Sin embargo, el problema surge cuando se sabe que ninguno de estos diseños solares pertenece al arte rupestre cubano. Valga entonces el razonamiento de duda razonable sobre las comparaciones morfológicas y su manejo mitológico como indicadores culturales aislados, independientes o absolutos. Además, es este el momento de dejar establecido, ante el planteamiento de que "[...] es fácil identificar [...] a la deidad suprema de los yoruba: Olórum[...]" (La Rosa, 2007: 81), que varios antropólogos cubanos, dedicados al estudio de las religiones afrocubanas, han señalado en más de una ocasión que para los yoruba existe una considerable distancia epistemológica entre Olórum y el sol (Guanche y Campos 2000: 27-28). 


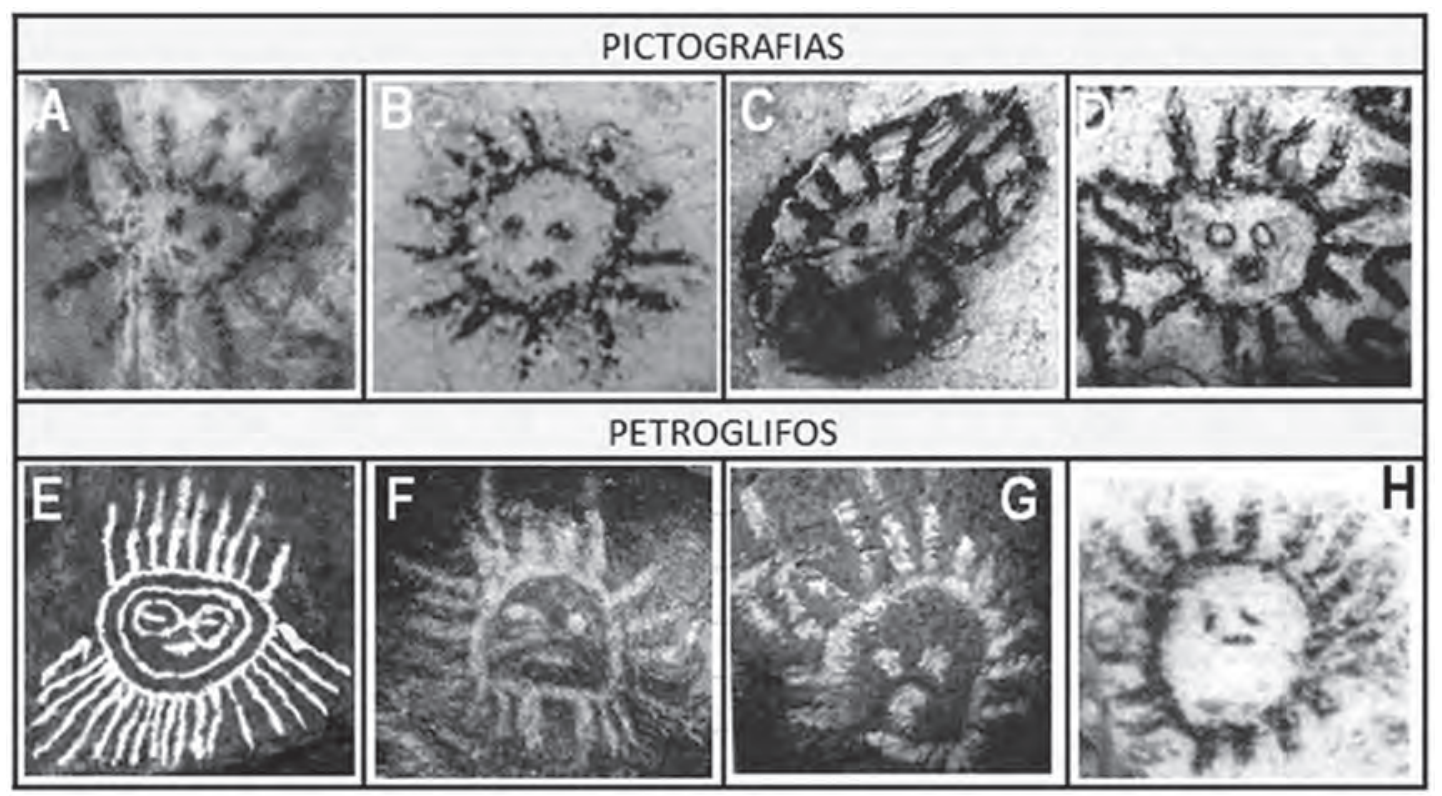

Figura 5. Diferentes imágenes solares con rostros del arte rupestre del Caribe insular (Composición elaborada por los autores a partir de López Belando 2003).

Ahora bien, volviendo a Cuba y su arte rupestre (Fig. 6), valga citar lo planteado por Pereira, al referirse a esta problemática:

Cabe mencionar que las culturas aruacas no representaron la imagen del sol y de la luna solamente con círculos concéntricos, sino también con rostros humanos en su interior, lo cual se conoce en muchas cuevas de nuestro país y el Caribe; por solo mencionar un caso, es la pictografía No. 4 de la Cueva de las Mercedes ubicada en Camagüey, Cuba (Pereira 2008:31).

Para continuar estos comentarios críticos sobre los métodos utilizados para intentar demostrar la presencia africana en la ejecución del arte rupestre cubano, nos referiremos al que probablemente sea el caso más discutido en el país: el de las cuevas de Guara, al sur de la provincia Mayabeque.

Estas estaciones fueron dadas a conocer públicamente en 1975, por A. Núñez Jiménez quien, ya entonces, consideró que la definición de la filiación cultural para estas espeluncas era un serio problema. De esta forma, sus propuestas fueron desde los aborígenes pre y postcolombinos hasta los históricos (Núñez 1975: 9 y 103). Muchos son los autores que han opinado sobre el tema; pero la última propuesta detallada en este sentido fue la realizada por La Rosa (2007), que al referirse a estas localidades, nos dice: "Se trata de una escena en que el sujeto percibe el movimiento y lo deja plasmado, nivel de representación no alcanzado nunca en el arte aborigen de Cuba. Además, en otras dos de las pinturas rupestres existen escenas de caza de grandes animales con cuernos" (La Rosa 2007: 72).

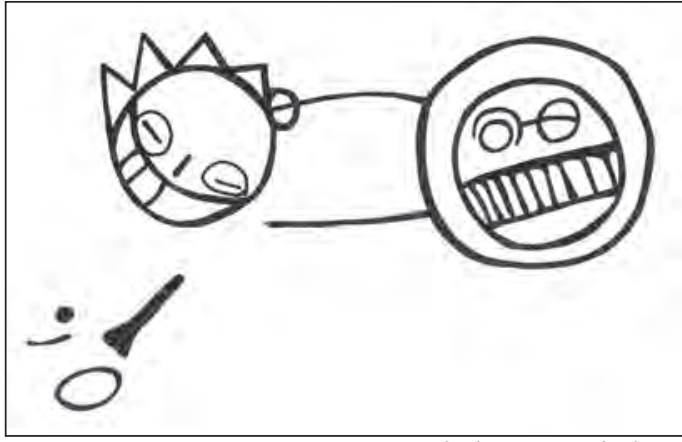

Figura 6. Pictografía número 4 de la Cueva de las Mercedes, Sierra de Cubitas, Camagüey, Cuba, donde se aprecia una magnifica representación del Sol y la Luna (Fuente: Archivos del GCIAR). 
En el parecer de los autores de esta crítica, otros diseños pictográficos cubanos y antillanos reflejan la congelación del movimiento mencionada por el autor citado. Tal es el caso de la escena de tres figuras ecuestres en movimiento de la Cueva de los Generales, Camagüey, en la cual el artista, además, representó el movimiento en una perspectiva "en punto de fuga", de una calidad extraordinaria. Pero si esto no bastara, dicha capacidad quedó demostrada en varios otros ejemplos de la plástica rupestre antillana, como en la representación del típico chorro de agua que expulsan las ballenas, en una de las pinturas más interesantes del arte rupestre aborigen de la Cueva de la Línea, en la República Dominicana (Torres et al. 2011), o en el magnífico diseño de la caza de un ave mediante arco y flecha, presente en una de las estaciones rupestres del Parque Nacional del Este, también en la República Dominicana (Gutiérrez et al., 2008). En esta localidad, el arquero se representó en una columna estalagmítica de la cavidad, la flecha en otra estalagmita a unos metros de la anterior -dándole al conjunto una sensación de la flecha en vuelo- y, en la pared de la cueva, frente a ambas formaciones, se dibujó el ave, objeto de la caza.

Mención aparte merece la definición de “cuernos", dada a los apéndices craneales que aparecen en las figuras de cuadrúpedos indeterminados del arte rupestre de Guara. ¿Qué argumento demuestra que dichos apéndices son cuernos y no, por ejemplo, orejas? ¿Qué se persigue con esta imposición morfológica, que no deja otra posibilidad? ¿Por qué no se acude a planteamientos más consecuentes con la realidad, como el de Oscar Pereira (2008: 33), cuando expresó que "[...] la imagen zoológica posee dos apéndices sobre la cabeza como si fueran tarros u orejas proyectadas hacia adelante[...]"?

Tal posición solo puede ser explicada por el afán de ubicar dichos animales en épocas postcolombinas, pues hasta hace muy poco no se tenía otra respuesta para la representación de grandes cuadrúpedos por parte de los aborígenes, como no fuera identificarlos con las especies introducidas a partir del descubrimiento y la conquista. Tanto es así, que todavía existen investigadores que continúan refiriéndose a los representantes del orden Pilosa como fauna del pleistoceno ${ }^{4}$ (Pereira 2008: 36 ).

Sin embargo, la arqueología moderna ha demostrado, por medio de la cronología absoluta y de la zooarqueología, que los grandes mamíferos del orden Pilosa, como Megalocnus rodens, vivieron en nuestro país hasta bien entrado el holoceno tardío. Así lo atestiguan los fechados C14 - AMS calibrados de $4960 \pm 280$ años AP, para Parocnus brownii, del sitio Las Breas de San Felipe (Steadman et al. 2005: 11765); y el de $4190 \pm 40$ a. AP, para Megalocnus rodens, de la Solapa del Sílex (MacPhee, R. D. E. et al. 2007: 96), esta última ubicada al sur de La Habana, con relativa cercanía a las cuevas de Guara. Asimismo, otros trabajos recientes han sugerido, con muchos elementos, que además de la convivencia temporal y espacial entre miembros del orden Pilosa y los aborígenes, es muy probable que existiese una interacción cultural (Rodríguez 1988: 563; Izquierdo et al. 2003: 55). ¿Por qué, entonces, emplear el término "cuernos", con su intensa carga de inducción cronológica y hasta cultural, para los diseños zoomorfos de las cuevas de Guara, si la evidencia arqueológica ha demostrado, para esta localidad, tanto la presencia de artefactos históricos como de restos precolombinos?

Otro caso particular es el de la Cueva de las Avispas, del municipio Quivicán, provincia Mayabeque, donde aparece un importante petroglifo antropomorfo con un diseño en su mano izquierda, que ha sido interpretado como la representación de un arco. Sobre esta localidad y los debates que ha suscitado, remitimos a los trabajos "Representaciones de arqueros en el dibujo rupestre de Cuba. Consideraciones generales" y "Notas sobre los arqueros del arte rupestre cubano", publicados, el primero, en el no. 19 de la revista Catauro (Gutiérrez et al. 2007) y, el segundo, en el no. 42 del Boletín del Museo del Hombre Dominicano (Gutiérrez et al. 2008). Solo es de destacar que la insistencia entre líneas que se puede entrever en algunos artículos sobre el arte rupestre cubano, donde se intenta vincular la representación de figuras de arqueros con autores africanos o afrodecendientes, tropieza con la realidad que impone el hecho de que la arqueología cubana solo ha logrado recuperar, hasta hoy, dos

4 Desde hace 1.64 millones de años hasta los 8000 a.C. 
evidencias materiales de esta arma herramienta: la flecha de Malpotón y la flecha de la Laguna del Tesoro, y ambas son de manufactura aborigen (Gutiérrez, et al. 2008: 337).

Otro ejemplo de los problemas metodológicos que aquí se discuten se refleja en el desarrollo de la tesis sobre la morfología de diseños rupestres y su similitud con deidades del panteón mitológico africano o afrocubano, cuando generalmente se concluye con la asignación a estas imágenes de funciones vinculadas a las deidades supuestamente representadas.

Lo anterior queda explícito en el siguiente párrafo: "[...] sus funciones [de los petroglifos] nos llevan necesariamente a que se trató de un centro de culto, en el que se efectuaron o preparó la celebración de algún tipo de rito de carácter mistérico de algunas religiones de origen africano que se desarrollaron en Cuba[...]" (La Rosa 2007: 82).

Una sencilla organización de esta cita y de los comentarios anteriores nos esclarece un proceder en función de un criterio que no se desprende de la investigación, sino todo lo contrario: el análisis se encausó en pos de un resultado predeterminado:

1. La morfología de los grabados es similar a la representación de deidades del panteón afrocubano (se obvian otras similitudes y otras relaciones).

2. A partir de esa relación se le asignan funciones compatibles con las de las deidades relacionadas.

3. Dicha relación entre morfología y funciones asegura su origen africano.

Ante tal enfoque reduccionista, donde no caben opciones paralelas ni duda razonable, la línea de pensamiento es convertida en un círculo forzosamente cerrado. Entonces, surge una pregunta: ¿La representación de una deidad afrocubana podría cumplir funciones entre nuestros pueblos aborígenes; o las supuestas funciones de estas deidades podrían indicar o sugerir otro origen que no fuera el afrocubano? O sea, toda la desagregación etnográfica está condicionada por un presupuesto inicial: "estamos ante la representación de una deidad afrocubana", y a este presupuesto se arriba solo por comparación morfológica, cuando además se deja a un lado la inmensa cantidad de opciones que nos ofrece el conocimiento del arte rupestre de todo el Caribe insular; región donde se desarrollaron los procesos etnoculturales que dieron forma a nuestra identidad.

Por otra parte, al asignar a un diseño rupestre funciones relacionadas con una deidad, con su carga de especificación restrictiva, y estas, a su vez, "asegurar" su origen cultural, se asume un proceder que nos recuerda el funcionalismo anglosajón; corriente superada por la rupestrología cubana, pues el criterio de función, al menos en arte rupestre, para que concluya con un enfoque satisfactorio, debe cuidarse de no ser extremadamente específico, con relación a un fin en particular (Consens, 1997: 107).

Finalmente, resulta incómodo -teniendo en cuenta los problemas que hoy se reconocen como limitantes en el estudio del arte- que surjan expresiones como la siguiente: "[...] lo que resulta incuestionable, es que los petroglifos y esculturas de la Cueva de los Ídolos no guardan relación alguna con el arte aborigen de los grupos aruacos que poblaron la isla, y sí en cambio tienen una estrecha relación con la cultura, mitos y cultos de origen africano" (La Rosa 2007: 82-83).

De todo lo anterior se desprende que, a pesar de que para el doctor Gabino La Rosa muchas de sus deducciones tienen un carácter "incuestionable", existen sólidos argumentos para afirmar que muchos de los procedimientos y métodos de análisis, utilizados para llegar a dichas deducciones, carecen al menos de una muestra que abarque un universo representativo del arte rupestre cubano y caribeño. Así, muchísimas de la conclusiones propuestas no se ajustan para nada al conocimiento rupestrológico que del Caribe insular que se posee en la actualidad, lo que sin dudas las convierte en un resultado muy alejado de lo que se ha definido como "una respuesta acabada al problema" (La Rosa 2007: 73).

Se registran otros casos importantes, dentro de toda esta problemática, cuando algunos investigadores ofrecen opiniones y apreciaciones personales como conclusiones infalibles, aparentemente 
bien argumentadas, derivadas de un estudio supuestamente detallado que, por el contrario, nunca es presentado. Pongamos un ejemplo. En el trabajo titulado "Cueva del Agua y del Hueso: patrimonio arqueológico en La Habana” (Garcell 2009), refiriéndose al arte rupestre de la Cueva del Agua, en la provincia Mayabeque, se puede leer lo siguiente: “Al comienzo de los estudios en el lugar se reportó la existencia en las paredes de la espelunca de dos amplios conjuntos pictóricos, atribuido el primero de ellos a las comunidades nativas con una economía de apropiación y el segundo a grupos humanos de origen afrodescendiente que utilizaron también la cueva como asilo temporal" (Garcell, 2009: 108). Nunca se informa quién los atribuyó de esa manera y bajo qué presupuestos.

Más adelante, se subraya de forma sencilla la supuesta significación de estos diseños: "Se destaca el conjunto número 1, de 1,5 $\mathrm{m}$ de largo por 1,5 m de alto, compuesto por ocho figuras antropomorfas y con un alto significado ritual-performativo" (Garcell 2009: 109). O se propone la relación de "zonas" del diseño con la cosmogonía afrocubana: "Se pueden identificar en el conjunto la existencia de tres zonas bien diferenciadas, las que podrían asociarse a niveles cósmicos del modelo mundo (mitopoética) del hombre religioso de origen afrodescendiente" (Garcell 2009: 109).

Aun cuando las evidencias arqueológicas encontradas en la Cueva del Agua, durante muchísimos años de trabajo, apuntan a su vinculación con distintos periodos de ocupación, hasta hoy ninguna investigación ha demostrado, por ningún método, la filiación cultural del arte rupestre de esta localidad. Tampoco lo logra el trabajo citado, donde nunca se explica cómo se llega a la conclusión del significado ritual-performativo de los diseños; o cómo se asocian zonas del diseño con niveles cósmicos de los modelos religiosos de individuos de origen "afrodescendiente"; ni se explica por qué "afrodecendientes", y no africanos propiamente, de los miles que fueron traídos a nuestras tierras durante la colonia. En fin, solo se dan supuestas conclusiones, pero nunca se nos introduce en la lógica del análisis. De ahí la obvia imposibilidad de aceptar como científicamente desarrollada y argumentada dicha propuesta.

Otro caso, relacionado con el anterior, muestra conclusiones del mismo tipo, pero diluidas dentro de trabajos que sí son portadores de importantes resultados sobre el tema. Un ejemplo sería el artículo "La confluencia del arte rupestre aborigen y de esclavos cimarrones en las cuevas de Cuba", de Oscar Pereira Pereira (2008). En él se puede leer, refiriéndose al arte rupestre de la Cueva de los Ídolos: "Los correspondientes análisis realizados en la morfología y la técnica de ejecución empleada en los petroglifos brindaron base a los arqueólogos para confirmar la hipótesis defendida por Fernando Ortiz"5 (Pereira 2008: 36). Sin embargo, ni en este trabajo, ni en ningún otro, ha sido presentado un análisis detallado de la técnica de ejecución de los petroglifos de la Cueva de los Ídolos, que permita exponer argumentos serios para su definición cultural. Tales naufragios metodológicos pueden condicionar en el lector una visión distorsionada de la realidad, aun en trabajos como el presentado por Pereira, el cual es, sin lugar a dudas, el enfoque más serio, detallado, exitoso y comprometido con una historia real, que se ha presentado sobre esta problemática de la rupestrología cubana.

El conjunto de los análisis hasta aquí realizados, sobre las propuestas de vinculación entre diseños rupestres cubanos y esclavos africanos o descendientes de africanos, permite llegar a una conclusión parcial: muchos de los investigadores que han estudiado el arte rupestre cubano en general, y el asociado supuestamente a un origen africano, en particular, pueden ser, y de hecho lo son, valiosísimos investigadores, con un vasto conocimiento de la arqueología cubana; pero, a su vez, revelan un importante desconocimiento del arte rupestre antillano y caribeño, además de evidenciar poco dominio de los alcances y limitaciones que presentan los modelos teórico-metodológicos de la rupestrología contemporánea.

5 Según el sabio cubano don Fernando Ortiz, era muy probable que estos diseños fueran realizados por cimarrones de origen africano (Pereira 2008: 36). 


\section{EL DESARROLLO DE LA RUPESTROLOGÍA Y UNA HIPÓTESIS EN ESPERA}

La rupestrología moderna precisa describir aquello que constituye su objeto de estudio. Esta pudiera parecer una simple tarea; pero nada más lejos de la realidad, puesto que tal operación implica un reconocimiento, para el cual se hace necesario un código en el cual "encajar" aquello que observamos. Este código necesita definir y jerarquizar los criterios taxonómicos, cosa que, como hemos analizado hasta aquí, no se ha efectuado, cuando de la posible elaboración de arte rupestre cubano por grupos de origen africano se trata.

Lo que se ha hecho, hasta hoy, en la mayoría de las propuestas, es incorporar como herramienta para la defensa de esta hipótesis un grado indescriptible de conceptualismos y apreciaciones personales, convertidas en teorías supuestamente sustentables, cuyas claves son generalmente imposibles de descodificar. Como ya expresamos, ha primado el supuesto reconocimiento en líneas cruzadas de cruces católicas; o la reconstrucción y comparación de una especie a partir de imágenes incompletas o fraccionarias; o se les ha asignado la etiqueta de "cuernos" a apéndices que bien podrían ser orejas. Peor aún, se ha asignado y personalizado una función mítica concreta, a partir de "una forma"; o se ha insinuado a priori que las dimensiones de determinadas pintura rupestre pueden definir su filiación cultural; o casi se les ha prohibido a nuestros aborígenes dibujar soles con caras en sus sitios ceremoniales; o sea, se ha preferido, "ante la duda, elegir", en lugar de "ante la duda, abstenerse".

A modo de conclusión: somos del criterio de que, frente a este conjunto de opiniones, a veces discrepantes, la hipótesis de la posible ejecución de imágenes del arte rupestre cubano por africanos traídos a nuestra tierra como esclavos y obligados a convertirse en cimarrones, o por sus descendientes, ha presentado, hasta el momento, suficientes limitaciones metodológicas y de procedimientos, como para sentirnos satisfechos con las propuestas presentadas y aceptar, como un hecho demostrado, los planteamientos formulados.

El cimarronaje (tanto por africanos originarios, como por su descendencia), en su relación con el arte rupestre, fue portador de un conjunto de signos, símbolos e ideogramas que configurarían una expresión artística de neoafricanidad, pues es el resultado de la adaptación y supervivencia en nuevas condiciones socioecológicas. Por ello, tenemos que asumir que fue inevitable el contagio con patrones y elementos impositivos de la cultura hispano-criolla. Esta realidad no ha sido explicada en los estudios rupestrológicos cubanos.

La respuesta a este problema deberá ser mucho más seria y complicada, y depende de los enfoques teóricos y metodológicos que apliquemos a los estudios. Llegar a la sugerida "respuesta acabada" requiere de un esfuerzo para comprender que los lugares con arte rupestre no deben ser considerados como un agregado de imágenes aisladas, sino como un conjunto en el que las conexiones son claves para el entendimiento; asumiendo un cambio tanto en el modo de pensar, como en la manera de enfocar la investigación.

Por ejemplo, en repetidas ocasiones se ha señalado, en el estudio de la Cueva de los Ídolos, aquí comentado, que muchos de sus petroglifos estaban cubiertos de raíces y fueron destapados. ¿Por qué, entonces, no se mantuvo ese estatus en un sector y no se tomaron muestras de dichas raíces? Ello hubiera permitido realizar estudios de crecimiento de talus, que proporcionarían un acercamiento a su cronología con algún margen de certeza, en lugar de especular acerca de que podrían tener una antigüedad de un siglo antes del hallazgo de Von Bandat en 1938 (La Rosa 2007: 79). En este sentido, es también llamativo el señalamiento de que la coloración de algunos petroglifos "es producto de la humedad y la presencia de microrganismos" (La Rosa 2007: 79). Entonces ¿por qué no se acudió a métodos más eficientes y no se trató de recuperar microorganismos que, por ejemplo, podrían haber contenido líquenes, que permiten estudios de cronología absoluta por liquenometría (Gutiérrez y Arrazcaeta 2011 [en prensa]), lo que nos aseguraría una posición mucho más sólida en cuanto a la antigüedad de los petroglifos? 
En otro orden, se comenta, también en más de una ocasión, que los petroglifos de la Cueva de los Ídolos resultan de hechura tosca y sin retoques, o de hechura defectuosa (La Rosa 2007: 80); pero la realidad es que, hasta ahora, no se ha enfocado una investigación hacia la interpretación de las trazas de ejecución de los diseños, de esta ni de ninguna otra de las estaciones que se han propuesto como sitios rupestres asociados al cimarronaje, lo que permitiría acercarse a los posibles instrumentos con que se realizaron. Esta línea de investigación aportaría importantes resultados, si aceptamos que el abanico de opciones de herramientas e instrumental con que contaron los cimarrones entre los siglos XVI al XIX es mucho más amplio y diverso que el accesible a los pueblos aborígenes del archipiélago cubano.

Tampoco se han realizado proyectos de investigación encaminados a obtener acercamientos a la localización, preparación y composición de los colorantes y herramientas utilizadas en la ejecución del arte rupestre de las estaciones supuestamente vinculadas a los africanos y el cimarronaje. Esta tarea solo ha sido llevada a cabo parcialmente para las cuevas de Guara (Arrazcaeta y García 2008: 64); pero resultados parciales y puntuales no aportarán soluciones ni respuestas a corto plazo. Se trata, en nuestra opinión, de la necesidad de un proyecto donde se analicen un número importante de variantes tecno-tipológicas, de los modos conceptuales y de procedimientos, presentes en el arte rupestre de un grupo considerable de estaciones, como la Cueva del Cura, del Abrón, del Garrafón, del Indio, de los Petroglifos, de María Antonia, de Camila, de los Ídolos, de las Avispas, de Paredones, de los Muertos, de los Matojos, del Aguacate, de Ambrosio, etc. En definitiva, existen toda una serie de recursos que nos permitirían elevar nuestro conocimiento sobre las especificidades, propiedades y características de los elementos con los que se trabajó en las estaciones que hoy se proponen como de probable factura africana.

Las implicaciones de estas propuestas metodológicas requieren no solo cambiar significativamente la forma de pensar, sino también la forma de abordar y trabajar los sitios rupestrológicos: la impaciencia por ver la morfología de un diseño no puede predominar ante la necesidad de conservar su cobertura vegetal o microbiológica, pues en esta puede estar la respuesta acertada y definitiva a importantes problemas teóricos.

Con el apoyo de estas propuestas y de muchas más, que son necesarias para la evaluación de cada caso en particular, así como con la utilización de técnicas de análisis más depuradas, se lograrían resultados de gran interés, que permitirían verdaderos acercamientos científicos a las distintas manifestaciones artísticas y a las supuestas manos africanas que las practicaron. A la perspectiva de la recuperación morfológica hay que agregarle los requerimientos de la nueva rupestrología, y renunciar definitivamente a la lectura iconográfica -realizada como si se pretendiera leer la leyenda de un mapa-, pues el arte rupestre es un elemento dependiente de la estructura de la sociedad en que se ejecutó y de su relación con el entorno. Ello hace posible, entonces, que un mismo signo pueda tener significados diferentes según su utilización dentro de los estratos que determinan la ideología, o según su posición en la estación, o en correspondencia con su signo vecino, etc.

Es evidente que una figura de cruz puede tener numerosas implicaciones dentro de las estratificaciones sociales (en cualquier sociedad), que no podemos sintetizar en el concepto reduccionista y contemporáneo de "cruz católica". Para ejemplificar nuestra afirmación, baste solo decir que en la actualidad un icono en forma de cruz, cuyos signos vecinos inmediatos, anteriores y posteriores, sean números, es inmediatamente interpretado como un signo de sumatoria, y nada tendrá que ver con una expresión ideológica o religiosa. Esta simple reflexión indica que, en todos los tiempos, las representaciones han estado condicionadas por el propio funcionamiento de la sociedad y sus necesidades, pero nunca estrictamente por su morfología, lo cual ha sido enunciado y repetido por importantes especialistas, así como comprobado para muchas partes del mundo, como se aprecia en las siguientes líneas: 
La cruz aparece frecuentemente relacionada con los puntos cardinales Norte, Sur, Este y Oeste, al mismo tiempo simboliza la elevación del alma o espiritu y la aspiración a la inmortalidad, deviene como la unidad de la vida y la muerte, puede simbolizar la fecundidad, el espíritu, el principio masculino, está relacionada con cultos fálicos; las cruces fueron utilizadas en imágenes de animales estilizados, así como en emblemas religiosos desde el Egipto antiguo, el cristianismo, hasta nuestra época, etc. (Toporov et al. 2002: 123 y 139).

Emprender esta nueva visión de una forma eficaz no será posible sin la ayuda de nuevas y potentes herramientas, ligadas a la gestión de los datos seleccionados. Pero de nada servirá una nueva herramienta, o un nuevo método, si las preguntas que realizamos al registro rupestrológico permanecen siendo las tradicionales, pues no se pueden seguir proponiendo filiaciones culturales para el arte rupestre cubano sin conocer a fondo las evidencias específicas en las que debería basarse la comprobación de sus presupuestos. Hace mucho que dejamos atrás los tiempos en que se podían asumir procesos de investigación rupestrológica sin una fundamentación teórica que diera sentido al proceso de análisis.

Entonces, hasta tanto no se asuman estos presupuestos de forma teórica y práctica durante los proyectos de investigación, la hipótesis sobre la posible ejecución de arte rupestre en las cuevas de Cuba por africanos, traídos a nuestro país entre los siglos XVI al XIX, seguirá esperando por procedimientos metodológicos y de análisis que la acerquen, al menos, a un discurso coherente. En la actualidad, debemos considerarla una hipótesis en espera de su adecuada documentación científica.

\section{Agradecimientos}

Queremos dejar constancia escrita de nuestro más sincero agradecimiento al Dr. Jesús Guanche y la Dra. Niurka Núñez, por la revisión de los originales y sus importantes sugerencias, imprescindibles en la construcción final de nuestro discurso. Un agradecimiento impostergable para el Dr. Miguel Barnet y todo el equipo de trabajo de la Fundación Fernando Ortiz, por su constante colaboración con nuestro modesto trabajo. Finalmente, al colega y amigo MSc. Jorge Ulloa, por la ayuda prestada en la elaboración definitiva de este proyecto.

\section{BiBLIOGRAFÍA}

ARRAZCAETA, Roger y Robin GARCÍA

2008 "La Región Pictográfica de Guara: Propuesta de una nueva hipótesis explicativa". El Caribe Arqueológico (11): 54-67, Santiago de Cuba.

BEDNARIK, Robert

2000 "Some problems with direct dating of rock-pictures". In G. K. Ward and C. Tuniz (eds), Advances in dating Australian rock-markings. Occasional AURA Publication 10: 104-109, Australian Rock Art Research Association.

CONSENS, Mario

1997 San Luís - El Arte Rupestre de sus sierras. Colección Investigación, 52-12, Fondo Editorial San Luiseño, Gobierno de la Provincia de San Luís.

FARIÑAS, Deisy

1995 Religión en las Antillas. Editorial Academia, La Habana.

FERNÁNDEZ, Racso; Divaldo GUTIÉRREZ, José GONZÁLEZ y Juan CUZA

2012 Aon. El perro precolombino de las Antillas. Fundación Fernando Ortiz. Manuscrito de 253 p. En prensa.

FUNES, Roberto

2005 Camagüey en la arqueología aborigen de Cuba. Ed. Ácana, 77 p. Camagüey.

GARCELL, Jorge núm. 2: 108 -110, <www.cubaarqueologica.org> 
GONZÁLEZ SÁNCHEZ, María Rosa

2008 "Consideraciones generales y primera aproximación al estudio de las pictografías en sitios arqueológicos de cimarrones en Pinar del Río". CD Conferencia Internacional Antropología 2008, Simposio Internacional de Arte Rupestre.

GUANCHE, Jesús y G. CAMPOS

2000 Artesanía y religiosidad popular en la santería cubana: el sol, el arco y la flecha, la alfarería de uso ritual. Ediciones Unión, La Habana.

GUTIÉRREZ, Divaldo, Racso FERNÁNDEZ y José GONZÁLEZ

2007 "Representaciones de arqueros en el dibujo rupestre de Cuba. Consideraciones generales". Catauro 9 (16):102-128, La Habana.

2008 "Notas sobre los arqueros del arte rupestre cubano". Boletín del Museo del Hombre Dominicano. XXXV (42): 331-355, Santo Domingo.

GUTIÉRREZ, Divaldo y Roger ARRAZCAETA

2011 [en prensa] "La datación en el arte rupestre. Métodos, actualidad y expectativas para Cuba". Boletín Gabinete de Arqueología, Oficina del Historiador de la Ciudad de la Habana.

IZQUIERDO, Gerardo, Ricardo SANPEDRO y Raúl VILLAVICENCIO

2003 "Oquedades Cársicas: Fauna Pleistocénica y Evidencias Arqueológicas. Provincia de Villa Clara, Cuba". El Caribe Arqueológico (7): 50 - 58, Santiago de Cuba.

JIMÉNEZ, Osvaldo y José FERNÁNDEZ

2002 "Cánidos precolombinos de las Antillas: mitos y verdades". Boletín Gabinete de Arqueología, Oficina del Historiador de la Ciudad de la Habana, 2 (2): 78-87.

LA ROSA, Gabino

1992 "El petroglifo de la Cueva de las Avispas, Quivicán, La Habana". Carta Informativa No. 9, Época III, Departamento de Arqueología, Centro de Antropología, Academia de Ciencias de Cuba.

2007 "Espacios míticos africanos en las cuevas de Cuba: Una hipótesis perturbadora". El Caribe Arqueológico (10): 69-84, Santiago de Cuba.

LA ROSA, Gabino, Alexis RIVES, José TOMÉ, Ovidio ORTEGA y Gabriel GARCÍA

1990 “El petroglifo de la Cueva del Indio". Carta Informativa No. 7, Época III, Departamento de Arqueología, Centro de Antropología, Academia de Ciencias de Cuba.

LÓPEZ, Adolfo

2003 Arte en la Penumbra. Ed. auspiciada por Grupo BHD, S.A., Coral Hotels and Resorts, Proempresa y Fondo Europeo de Desarrollo, Santo Domingo, 359 p.

MACPHEE, Ross, Manuel ITURRALDE-VINENT y Osvaldo JIMÉNEZ

2007 "Prehistoric Sloth Extinctions in Cuba: Implications of a New Last Appearance Date". Caribbean Journal of Science, Vol. 43 (1): 94-98. New York.

MOSQUERA, Gerardo

1983 Exploraciones en la plástica cubana. Ed. Letras Cubanas, La Habana.

NELSON, D. E.

1993 "Second thoughts on a rock art date". Antiquity 67: 893-5. New York.

NÚÑEZ JIMÉNEZ, Antonio

1975 Cuba: Dibujos Rupestres. Editorial Ciencia y Técnica, 705 p. La Habana.

1985 Arte Rupestre de Cuba. Ed. Jaca Book, 123 pp. Torino.

OLIVER, José

1998 El Centro Ceremonial de Caguana, Puerto Rico. Simbolismo iconográfico, cosmovisión y poderío caciquil Taíno de Boriquen. Archaeopres, British Archaeological Reports: 232.

PEREIRA, Oscar

2008 "La confluencia del arte rupestre aborigen y de esclavos cimarrones en las cuevas de Cuba". El Caribe Arqueológico (11): 28-41, Santiago de Cuba. 
RODRÍGUEZ, Roberto

1988 "La convivencia de la fauna de desdentados extinguidos con el aborigen de Cuba". Kobie. Rev. Cien., (14): 561-566, Bilbao.

STEADMAN, David, Paul S. MARTIN, Ross MACPHEE, A. J. T. JULL, Gregory MCDONALD, Charles WOODS, Manuel ITURRALDE-VINENT y Gregory HODGINS

2005 "Asynchronus extinction of late Quaternary sloths on continents and islands". PNAS, 102 (33): 11763-11768.

TOPOROV, Vladimir, Viacheslav IVANOV y Eleazar MELETINSKI

2002 Árbol del mundo: Diccionario de imágenes, símbolos y términos mitológicos. Colección Criterios. Casa de las Américas, UNEAC, La Habana.

TORRES, Liamne, Divaldo GUTIÉRREZ, José GONZÁLEZ, Racso FERNÁNDEZ, y Clenis TAVÁREZ

2011 "Reflexiones sobre el papel de las ballenas en comunidades aborígenes del Caribe Insular. República Dominicana, un caso de ejemplo". Revista ANTI, Centro de Investigaciones Precolombinas de Buenos Aires (10): 14-24.

VAN DER KLIN, Heleen

1992 "Faunal Remains of Golden Rock". The Archaeology of the St. Eustatius. The Golden Rock, Site. (Ed) Aad H.Versteeg y Kess Scinkel. St. Eustatius Historical Foundation y Foundation for Scientific Research in the Caribbean Region. 2, (131): 74-83.

VELOZ, Marcio

S/F Pipas indígenas de Santo Domingo y Puerto Rico. Cuadernos CENDIA Vol. CCLX, No. 4, 12 p., Santo Domingo. 